\title{
Pembuktian Pembajakan Hak Cipta atas Karya Digital Melalui File Sharing di Indonesia
}

\section{Proof of Copyright Piracy of Digital Works through File Sharing in Indonesia}

\author{
Riswan Hanafyah Harahap \\ Dinas Lingkungan Hidup dan Kehutanan Kota Kendari \\ E-mail:mcrizzwan@outlook.com \\ Deity Yuningsih \\ Pascasarjana Universitas Halu Oleo \\ E-mail: deityhukum@gmail.com \\ Zahrowati \\ Pascasarjana Universitas Halu Oleo \\ E-mail: zahrowati.s3@gmail.com
}

\begin{abstract}
This study aims to obtain data which will then be processed and analyzed, so that in the end it can be proposed various recommendations aimed at finding out the evidence of copyright piracy on digital works through file sharing in Indonesia. And to understand civil settlements related to copyright piracy on digital works through file sharing in Indonesia. The writing method used in this research is a normative writing method with a statute approach and a conceptual approach. The results show that the form of proof of copyright piracy on digital works through file sharing in Indonesia is generally the same as evidence in civil procedural law, namely the principle of actori incumbit probatio which means whoever has a right or proposes an event must prove the existence of that right or event. Regarding evidence also has similarities, but because the domain of piracy of digital works through file sharing is with computer media or the like so that electronic evidence is possible, which has technical obstacles in the form of proving the originality of the evidence presented and non-technical obstacles in the form of vulnerability to damage and loss of stored electronic evidence, in addition to the form of civil settlement related to copyright piracy on digital works through file sharing in Indonesia is that there are several forms of copyright dispute resolution which are regulated in the copyright law, the settlement can be done through alternative dispute resolution, arbitration, or court.
\end{abstract}

Keyword: Evidence; Piracy; File Sharing

Abstrak: Penelitian ini bertujuan untuk memperoleh data yang kemudian akan diolah dan dianalisis, sehingga pada akhirnya dapat diusulkan berbagai rekomendasi yang ditujukan untuk mengetahui pembuktian pembajakan hak cipta atas karya digital melalui file sharing di Indonesia. Serta untuk memahami penyelesaian perdata terkait pembajakan 
hak cipta atas karya digital melalui file sharing di Indonesia. Metode penulisan yang digunakan dalam penelitian ini adalah metode penulisan normatif dengan pendekatan undang-undang (statute approach) dan pendekatan konseptual (conceptual approach). Hasil penelitian menunjukkan bahwa bentuk pembuktian pembajakan hak cipta atas karya digital melalui file sharing di Indonesia adalah pada umumnya sama dengan pembuktian dalam hukum acara perdata yakni asas actori incumbit probatio yang berarti barang siapa mempunyai sesuatu hak atau mengemukakan suatu peristiwa harus membuktikan adanya hak atau peristiwa itu. Mengenai alat bukti juga memiliki kesamaan namun karena domain pembajakan atas karya digital melalui file sharing adalah dengan media komputer atau sejenisnya sehingga dimungkinkan alat bukti elektronik, yang memiliki kendala teknis berupa pembuktian orisinalitas dari alat bukti yang dihadirkan dan kendala non teknis berupa rentannya kerusakan serta hilangnya barang bukti elektronik yang disimpan, selain itu bentuk penyelesaian perdata terkait pembajakan hak cipta atas karya digital melalui file sharing di Indonesia adalah terdapat beberapa bentuk penyelesaian sengketa hak cipta yang diatur dalam Undang-Undang Hak Cipta, penyelesaian tersebut dapat dilakukan melalui alternatif penyelesaian sengketa, arbitrase, atau pengadilan.

Kata kunci: Pembuktian; Pembajakan; File Sharing

\section{PENDAHULUAN}

Di era teknologi saat ini yang semakin modern, manusia dituntut untuk dapat beradaptasi dengan masifnya perubahan-perubahan dibandingkan dengan tahun-tahun sebelumnya. Perkembangan zaman yang semakin pesat tentunya akan mempengaruhi gaya hidup dari masyarakat yang sebelumnya tradisional menjadi lebih modern, termasuk dengan melakukan berbagi berkas melalui internet. File sharing atau berbagi berkas sendiri merupakan kegiatan yang dilakukan oleh pengguna untuk berbagi berkas-berkas dalam bentuk digital, baik itu dokumen, musik, video, software (perangkat lunak), dan sebagainya. Hal ini dapat dilakukan secara pribadi maupun secara publik dengan memberikan izinnya pada berkas-berkas tertentu.

Dengan adanya layanan file sharing, maka kegiatan berbagi berkas sendiri dapat memudahkan masyarakat untuk berbagi berkasnya tersebut untuk siapa saja, baik untuk kalangan pribadi maupun untuk semua orang. Namun, penggunaan berbagi berkas sendiri tidak terlepas dari masalah baru yang akan muncul, yakni terkait dengan permasalahan pelanggaran hak cipta. Hal ini karena kemajuan teknologi file sharing telah memungkinkan konsumen untuk menyalin musik, buku, video game, dan karya yang dilindungi lainnya dalam skala yang belum pernah terjadi sebelumnya dengan biaya minimal ${ }^{1}$.

Menurut Direktur Jenderal Hak Kekayaan Intelektual Kementerian Hukum dan HAM Tahun 2011-2016 Ahmad M Ramli, maraknya pelanggaran hak kekayaan intelektual telah

1 Felix Oberholzer-Gee dan Koleman Strumpf, "File Sharing and Copyright," Innovation Policy and the Economy, Vol. 10, Januari 2010, hlm. 19, http://www.journals.uchicago.edu/doi/10.1086/605852. 
membuat Indonesia dikategorikan sebagai salah satu negara pembajak atau pelanggar hak kekayaan intelektual di dunia. Ia mengatakan selain pada barang berwujud, pelanggaran hak kekayaan intelektual juga marak terjadi pada barang tidak berwujud seperti lagu, film, software dan konten hak cipta lainnya. Umumnya, benda itu dijiplak tanpa seizin pemegang hak cipta melalui internet dengan cara file sharing, email, peer to peer dan cara-cara lain yang berkaitan dengan pembajakan konten ${ }^{2}$.

Dalam kaitannya dengan pembajakan yang terjadi di Indonesia, bisa dilihat dengan maraknya pembajakan film-film nasional dan internasional. Salah satunya dengan situs IndoXXI. IndoXXI adalah situs yang menyediakan layanan streaming/nonton film bajakan, serta memungkinkan untuk mengunduh film tersebut dengan menggunakan jaringan internet. Karena dengan sifat dari situs itu sendiri, Kementerian Komunikasi dan Informatika telah memblokir 1.130 situs web streaming ilegal atau bajakan, kurun Mei hingga Desember 2019. Salah satunya, situs IndoXXI ${ }^{3}$. Pada tanggal 1 Januari 2020, situs tersebut menyatakan telah menghentikan layanan mereka, seperti yang dikutip oleh Detikcom, yakni "Sangat berat tapi harus dilakukan, terima kasih kepada seluruh penonton setia kami, terhitung sejak tanggal 1 Januari 2020 kami akan menghentikan penayangan film di website ini demi mendukung dan memajukan industri kreatif tanah air, semoga ke depannya akan menjadi lebih baik," tulis IndoXXI ${ }^{4}$.

Sebelum situs ini ditutup, situs ini menampilkan film-film bajakan, mulai dari film nasional hingga film internasional, bahkan film yang belum ditayangkan secara resmi di Indonesia. Selain itu, ada fitur download, yang memungkinkan pengujung dapat mengunduh film tersebut tanpa membeli film tersebut. Situs itu memanfaatkan Google Drive dalam menyimpan film-film bajakan tersebut. Ketika pengunjung ingin mengunduh film tersebut, pengujung harus memiliki akun harus memiliki akun email terlebih dahulu di Google Drive ${ }^{5}$. Namun, IndoXXI menampik bahwa mereka menyimpan film-film bajakan mereka di server mereka, seperti yang dikutip oleh CNBC Indonesia, yakni "IndoXXI atau XXI tidak memiliki atau

2 Rafika Aulia, "Menteri Amir: Pelanggaran Hak Cipta Merugikan," Tempo.co, https://nasional.tempo.co/ read/399773/menteri-amir-pelanggaran-hak-cipta-merugikan, diakses pada tanggal pada tanggal 3 Maret 2020.

3 Iskandar, "Headline: Situs IndoXXI Tutup, Kemkominfo Blokir Massal Web Streaming Ilegal?," Liputan6.com, https://www.liputan6.com/tekno/read/4142549/headline-situs-indoxxi-tutupkemkominfo-blokir-massal-web-streaming-ilegal, diakses pada tanggal 3 Maret 2020,

4 Adi Fida Rahman, "Tepati Janji, IndoXXI Resmi Tutup Layanan," Detikcom, https://inet.detik.com/cyberlife/d-4842340/tepati-janji-indoxxi-resmi-tutup-layanan, diakses pada tanggal pada tanggal 3 Maret 2020

5 “2 Cara Download Film IndoXXI di Android atau Laptop Terbaru 2019," Kuotamedia.net, https://kuotamedia.net/hiburan/film/cara-download-film-indoxxi/, diakses pada tanggal 3 Maret 2020 
menyimpan konten di server sendiri, hanya mengambil tautan atau embed konten dari luar yang telah di upload ke situs-situs website populer seperti Youtube, Google Drive, Dailymotion, ZShare dan sejenisnya," tulisnya6.

Sementara itu, pada hari Kamis, 28 Januari 2021, Visinema Pictures resmi menggiring tersangka pembajakan karya Visinema Pictures berinisial AFP ke meja hijau untuk diadili di Pengadilan Negeri Jambi. Karya Visinema Pictures yang dicuri, diunggah, serta ditayangkan secara ilegal di platform website bernama DUNIAFILM21 adalah Keluarga Cemara. Film yang meraih 1,7 juta penonton bioskop pada awal 2019 itu diputar secara utuh atau ditayangkan secara online dengan cuma-cuma bagi pengunjung website tersebut? ${ }^{7}$

Pembajakan hak cipta melalui media file sharing sangat merugikan bagi pemilik dan pemegang hak cipta, serta merusak keuntungan secara ekonomi akibat yang ditimbulkan dari pembajakan tersebut. Hal ini dapat dilihat dari keuntungan yang didapatkan oleh situs pembajakan. Keuntungan pertama didapatkan dari iklan yang muncul dari situsnya. Alfons Tanujaya mencontohkan, dalam sehari situs IndoXXI diakses hingga 1 juta pengunjung per hari. Tidak hanya berhenti sampai di situ. Pada kasus pembajakan film Keluarga Cemara, AFP ternyata telah melakukan pembajakan terhadap sekitar 3.000 judul film lokal dan impor sejak 2018. Hal ini dilakukan untuk mencari keuntungan dari iklan yang didaftarkan, mengingat judul film-film tersebut cukup terkenal ${ }^{8}$.

Karya cipta dalam bentuk digital memang sangat mudah untuk diduplikasi dan hasil atas perbuatan tersebut juga nyaris tidak dapat dibedakan dengan aslinya berkat adanya sekarang dilakukan secara modern berkat adanya file sharing. Tidak hanya itu, orang pun kemudian dapat melakukan modifikasi terhadap hasil penggandaan dan mendistribusikannya ke seluruh dunia dengan nyaris tanpa biaya. Di satu sisi, hal ini tentu membuat sangat mudah bagi hampir semua orang untuk melanggar hak cipta orang lain dalam skala yang sangat besar, tetapi di sisi lain sangat sulit bagi pemilik hak cipta untuk mengetahui terjadinya pelanggaran, mengenali, atau pun kemudian melakukan upaya hukum9.

\footnotetext{
6 Arif Budiansyah, "Tutup Januari 2020, Ini Cara IndoXXI Dapat Film Baru \& Cuan," CNBC Indonesia, https://www.cnbcindonesia.com/tech/20191230073207-37-126373/tutup-januari-2020-ini-caraindoxxi-dapat-film-baru-cuan, diakses pada tanggal 4 Maret 2020

7 Dina Fitri Anisa, "Film Keluarga Cemara Dibajak, Visinema Pictures Giring Pelaku ke Pengadilan," Berita Satu, https://www.beritasatu.com/hiburan/725189/film-keluarga-cemara-dibajak-visinema-picturesgiring-pelaku-ke-pengadilan, diakses pada tanggal 10 Agustus 2021

8 Ibid.

9 Yusran Isnaini, Hak Cipta dan Tantangannya di Era Cyber Space, Bogor: Ghalia Indonesia, 2009, hlm. 28.
} 
Dalam hal ini, diperlukan pembuktian, apakah situs yang menyediakan karya digital dapat dimintakan ganti rugi akibat yang ditimbulkan. Selain itu, pembuktian sangat diperlukan untuk mengidentifikasi apakah dalam perbuatannya telah mendapatkan izin untuk menyebarluaskan secara digital melalui file sharing. Untuk menjawab permasalahanpermasalahan tersebut, perlu dilakukan penelitian lebih lanjut, sehingga penulis mengangkat penelitian ini yang berjudul "Pembuktian Pembajakan Hak Cipta Atas Karya Digital Melalui File Sharing di Indonesia".

\section{METODE PENELITIAN}

Metode penulisan yang digunakan dalam penelitian ini adalah metode penulisan normatif. Penelitian normatif maksudnya adalah bahwa dalam penelitian ini berpedoman kepada peraturan perundang-undangan yang berlaku (hukum positif) yang relevan dengan masalah yang diteliti ${ }^{10}$. Penelitian yang dilakukan oleh penulis berupa pendekatan undang-undang (statute approach) dan pendekatan konseptual (conceptual approach).

\section{ANALISIS DAN PEMBAHASAN}

Bentuk Pembuktian Pembajakan Hak Cipta Atas Karya Digital Melalui File Sharing di Indonesia

\section{Prinsip Umum Pembuktian dalam Peradilan Niaga}

Pembuktian adalah penyajian alat-alat bukti yang sah menurut hukum oleh para pihak yang beperkara kepada hakim dalam suatu persidangan, dengan tujuan untuk memperkuat kebenaran dalil tentang fakta hukum yang menjadi pokok sengketa, sehingga hakim memperoleh dasar kepastian untuk menjatuhkan keputusan ${ }^{11}$. Menurut M. Yahya Harahap, pembuktian mempunyai arti luas dan arti sempit.

Dalam pengertian yang luas, pembuktian adalah kemampuan penggugat atau tergugat memanfaatkan hukum pembuktian untuk mendukung dan membenarkan hubungan hukum dan peristiwa-peristiwa yang didalilkan atau dibantah dalam hubungan hukum yang diperkarakan. Sedangkan dalam arti sempit, pembuktian hanya diperlukan sepanjang mengenai hal-hal yang dibantah atau hal yang masih disengketakan atau hanya sepanjang yang

10 Hilman Hadikusuma, Metode Pembuatan Kertas Kerja atau Skripsi Ilmu Hukum, Bandung: Mandar Maju, 1995, hlm. 61.

11 Bahtiar Effendie, Tasmin Masdari, dan A. Chodari, Surat Gugat Dan Hukum Pembuktian Dalam Perkara Perdata, Bandung: Citra Aditya Bakti, 1999, hlm. 50. 
menjadi perselisihan di antara pihak-pihak yang berperkara ${ }^{12}$. R Subekti berpendapat bahwa pembuktian adalah suatu proses bagaimana alat-alat bukti dipergunakan, diajukan atau dipertahankan sesuatu hukum acara yang berlaku¹3.

Suatu sistem hukum merupakan suatu kesatuan aturan-aturan hukum yang berhubungan satu dengan lainnya, dan telah diatur serta disusun berdasarkan asas-asas. Asasasas hukum adalah aturan-aturan pokok yang tidak dapat lagi dijabarkan lebih lanjut, di atasnya tidak lagi ditemukan aturan-aturan yang lebih tinggi lagi. Asas hukum merupakan dasar bagi aturan-aturan hukum yang lebih rendah ${ }^{14}$.

Perbedaan antara asas hukum dengan peraturan yang lebih rendah adalah bahwa asas hukum lebih abstrak, apabila asas hukum tidak dimasukkan dalam undang-undang, tidak mengikat bagi hakim, melainkan hanya sebagai pedoman saja. Akan tetapi, bila asas itu secara tegas dituangkan dalam undang-undang, mempunyai kekuatan mengikat sebagai undangundang sehingga hakim berkewajiban untuk menerapkan asas tersebut secara langsung terhadap semua kasus-kasus nyata yang atasnya tidak terdapat aturan-aturan khusus ${ }^{15}$.

Di dalam pembagian beban pembuktian dikenal asas affirmandi incumbit probatio, yaitu siapa yang mendalilkan sesuatu dia harus membuktikannya, sebagaimana tercantum dalam Pasal 163 HIR/283 RBg. Hal ini secara sepintas mudah untuk diterapkan. Namun, sesungguhnya dalam praktik merupakan hal yang sukar untuk menentukan secara tepat siapa yang harus dibebani kewajiban untuk membuktikan sesuatu16. Menurut Peneliti, kewajiban untuk membuktikan sesuatu tersebut, terletak pada siapa yang mendalilkan seperti dalam gugatan, dalam hal ini adalah penggugat, namun apabila tergugat mengajukan dalil bantahannya, maka dia dibebani pula untuk membuktikan dalil bantahannya, dalam hal ini kesempatan untuk membuktikan dalilnya adalah penggugat yang kemudian diikuti oleh tergugat.

Membicarakan tentang penilaian keabsahan penggunaan alat bukti di dalam hukum acara pidana, terdapat prinsip yang sama dengan yang diatur dalam hukum acara perdata sebagaimana dimaksud Pasal 294 ayat (1) HIR. Pasal 183 KUHAP, pada asasnya mengatur

12 M. Yahya Harahap, “Kumpulan Makalah Hukum Acara Perdata”, Pendidikan Hakim Senior angkatan ke I Tugu Bogor, 1991, hlm. 1.

13 R. Subekti, Hukum Pembuktian, Jakarta: Pradnya Paramita, 1991, hlm. 7.

14 J.H.P. Bellefroid dalam buku Efa Laila Fakhriah, Efa Laela Fakhriah, Bukti Elektronik dalam Sistem Pembuktian Perdata, 2 ed., Bandung: Alumni, 2013, hlm. 44.

15 Ibid.

16 Retnowulan Sutantio dan Iskandar Oeripkartawinata, Hukum Acara Perdata dalam Teori dan Praktek, Bandung: Mandar Maju, 1995, hlm. 55. 
tentang17: "Hakim tidak boleh menjatuhkan pidana kepada seseorang kecuali apabila dengan sekurang-kurangnya dua alat bukti yang sah ia memperoleh keyakinan bahwa sesuatu tindak pidana benar-benar terjadi dan bahwa terdakwalah yang bersalah melakukannya."

Sedangkan, di dalam hukum acara perdata dalam rangka penilaian keabsahan penggunaan alat bukti tidak terdapat ketentuan semacam di atas, dan hanya mengenal prinsip pembuktian sebagaimana ditentukan dalam Pasal 163 HIR/283 RBg jo. Pasal 1865 KUHPerdata bahwa barang siapa menyatakan mempunyai hak atas suatu barang, atau menunjuk suatu peristiwa untuk meneguhkan haknya, ataupun menyangkal hak orang lain, maka orang itu harus membuktikannya.

Dari peristiwa itu, yang harus dibuktikan adalah kebenarannya. Dalam hukum acara perdata, kebenaran yang harus dicari oleh hakim adalah kebenaran formal, artinya bahwa hakim tidak boleh melampaui batas-batas yang diajukan oleh pihak-pihak yang beperkara. Pasal 178 ayat (3) HIR/Pasal 189 ayat (3) RBg, melarang hakim untuk menjatuhkan putusan atas perkara yang tidak dituntut, atau akan mengabulkan lebih dari yang dituntut ${ }^{18}$.

Ada suatu peristiwa yang tidak memerlukan pembuktian lagi karena kebenarannya sudah diakui umum, yang disebut peristiwa notoir (notoir feiten, noticeable facts). Setiap orang pasti mengetahuinya, sehingga majelis hakim harus yakin sedemikian adanya. Misalnya, sedang berlaku larangan keluar malam, tak seorang pun boleh keluar rumah kecuali petugas keamanan ${ }^{19}$.

Mengenai alat-alat bukti dan hukum pembuktian, selain diatur dalam HIR dan RBg, juga diatur dalam KUHPerdata. Akan tetapi, karena hukum pembuktian perdata merupakan bagian dari hukum acara perdata, pengadilan pada prinsipnya dalam menangani perkara perdata harus mendasarkan pada hukum pembuktian dari HIR dan RBg, sedangkan KUHPerdata hanya sebagai pedoman saja apabila diperlukan, misalnya dalam suatu perkara perdata harus dilaksanakan suatu peraturan hukum perdata yang termuat dalam KUHPerdata dan pelaksanaan ini hanya tepat jika hukum KUHPerdata yang diikuti20.

Pembuktian dalam perkara perdata, khususnya di Indonesia tidaklah terlepas dari Buku keempat KUHPerdata yang mengatur mengenai Pembuktian dan Daluwarsa. Selain

17 Johan Wahyudi, “Dokumen Elektronik Sebagai Alat Bukti Pada Pembuktian Di Pengadilan," Perspektif Vol. 17, No. 2, 2012, hlm. 122.

18 Efa Laela Fakhriah, Sistem Pembuktian Terbuka Dalam Penyelesaian Sengketa Perdata Secara Litigasi, Bandung: Universitas Padjajaran, 2012, http://pustaka.unpad.ac.id/wpcontent/uploads/2012/05/pustaka_unpad_sistem_pembuktian.pdf.

19 Abdulkadir Muhammad, Hukum Acara Perdata Indonesia, Bandung: Alumni, 1978, hlm. 116.

20 Wirjono Projodikoro, Hukum Acara Perdata di Indonesia, Bandung: Sumur Bandung, 1992, hlm. 107. 
KUHPerdata, masalah pembuktian perkara perdata di Indonesia juga diatur dalam Reglemen Indonesia yang dibaharui, Staatblaad 1941, Nomor 44 (RIB) dan di dalam Regelement Buiten Gewesten (RBG) atau Reglemen Daerah Seberang (RDS). HIR atau RIB hanya diperuntukkan bagi Jawa dan Madura, sedangkan RBG atau RDS diperuntukkan di luar Jawa dan Madura. Pembuktian dalam buku keempat KUHPerdata adalah aspek materiil dari hukum acara perdata, sedangkan pembuktian dalam RIB dan RDS mengatur aspek formil dari hukum acara perdata ${ }^{21}$.

\section{Bentuk Pembuktian Pembajakan Hak Cipta atas Karya Digital Melalui File Sharing}

Dalam aspek pembuktian terhadap pelanggaran hak cipta atas karya digital tentunya salah satu jenis karya digital yang dilindungi adalah karya yang berkaitan dengan karya sinematografi yang mana karya tersebut dilindungi oleh Undang-Undang Nomor 28 Tahun 2014 tentang Hak Cipta (UUHC) Pasal 40 yakni Ciptaan yang dilindungi meliputi Ciptaan dalam bidang ilmu pengetahuan, seni, dan sastra, dalam hal ini termasuk di dalamnya karya sinematografi.

Bentuk pembuktian terhadap pembajakan hak cipta atas karya digital melalui file sharing masih mengacu pada prinsip-prinsip pembuktian dalam hukum acara perdata pada umumnya yaitu prinsip "actori incumbit probatio", yakni siapa yang mengaku mempunyai hak harus dibebani dengan beban pembuktian. Pasal tersebut di atas merupakan kristalisasi dari asas sistem pembuktian, yaitu Actori incumbit probatio, yang merujuk pada siapa yang mendalilkan sesuatu maka ia yang harus membuktikan. Pun yang membantah akan suatu dalil maka ia juga memiliki kewajiban untuk membuktikan bantahannya.

Selain itu terdapat asas hukum: equal justice under law, suatu perlakuan yang sama terhadap para pihak, yang bermakna siapa yang lemah pembuktiannya harus dikalahkan. Begitu pun dengan alat bukti yang diajukan untuk membuktikan dan mendukung dalil gugatannya para pihak yang berperkara di Pengadilan Niaga dapat mengajukan alat-alat bukti seperti surat-surat, saksi-saksi, persangkaan, pengakuan; dan sumpah. ${ }^{22}$

Karena dalam hal pembuktian terhadap pembajakan hak cipta atas karya digital melalui file sharing adalah domain dari pembuktian digital atau pembuktian melalui elektronik dengan pendekatan teknologi maka jenis-jenis alat bukti tersebut pada umumnya tidak mungkin dapat terpenuhi, sehingga seiring dengan perkembangan teknologi informasi memiliki dampak yang cukup signifikan terhadap perkembangan hukum.

21 Teguh Samudera, Hukum Pembuktian Dalam Acara Perdata, 1 ed., Bandung: Alumni, 1992, hlm. 81.
22 Lihat Pasal 164 HIR dan Pasal 284 RBg. 
Tentang alat bukti elektronik, telah disebutkan dalam Pasal 5 Ayat 1 Undang-Undang Nomor 19 Tahun 2016 tentang Perubahan atas Undang-Undang Nomor 11 Tahun 2008 tentang Informasi dan Transaksi Elektronik (UU ITE) yang menyatakan bahwa informasi dan atau dokumen elektronik dan atau hasil cetaknya merupakan alat bukti yang sah dan memiliki akibat hukum yang sah.

Sejak UU ITE disahkan maka hukum pembuktian secara limitatif seperti yang ada dalam KUHPerdata. Alat bukti dapat dipercaya jika dilakukan dengan cara: ${ }^{23}$

a. Menggunakan peralatan komputer untuk menyimpan dan memproduksi print out;

b. Proses data seperti pada umumnya dengan memasukkan inisial dalam sistem pengelolaan arsip yang dikomputerisasikan;

c. Menguji data dalam suatu waktu yang tepat, setelah data dituliskan oleh seseorang yang mengetahui peristiwa hukumnya;

d. Mengkaji informasi yang diterima untuk menjamin keakuratan data yang dimasukkan;

e. Metode penyimpanan dan tindakan pengambilan data untuk mencegah hilangnya data pada waktu disimpan;

f. Penggunaan program komputer yang benar-benar dapat dipertanggung jawabkan untuk memproses data;

g. Mengukur uji pengambilan keakuratan program;

h. Waktu dan pengarsipan mode print-out komputer.

Syarat sahnya dokumen elektronik ialah apabila menggunakan sistem elektronik sesuai dengan ketentuan yang diatur dalam UU ITE, khususnya dalam Pasal 6 UU ITE yakni "informasi Elektronik dan/atau Dokumen Elektronik dianggap sah sepanjang informasi yang tercantum di dalamnya dapat diakses, ditampilkan, dijamin keutuhannya, dan dapat dipertanggungjawabkan sehingga menerangkan suatu keadaan". Selain itu, terdapat pula kekhususan dalam penyelenggaraan sertifikasi elektronik dan sistem elektronik serta transaksi elektronik.

Dokumen digital, surat elektronik, dan sebagainya bisa menjadi alat bukti surat. Karena saat ini dalam hingar-bingar kampanye paperless, dokumen digital dan surat elektronik menjadi vital. Dan hal ini diperkuat melalui keabsahan tanda tangan elektronik sesuai ketentuan Pasal 5 sampai Pasal 12 UU ITE. Dan ditambah lagi dengan keberadaan sertifikasi terhadap perangkat lunak sebagai penyedia layanan pembuatan tanda tangan elektronik. ${ }^{24}$

Rekam CCTV dalam perkara perdata bisa diinterpretasikan dalam alat bukti persangkaan, dimana penjelasan mengenai persangkaan bisa dilihat pada Pasal 1915

23 Dimas Febrian Syahputra, Rivan Kurniawan, dan Yusuf Bintang Syaifinuha, "Perlindungan Hukum Transaksi E-Commerce," Privat Law Vol. 7, 2015, hlm. 75.

24 "Alat Bukti Elektronik dalam Perkara Perdata," Michael Agusting \& Partners Lawyers, last modified 2017, diakses pada tanggal Juli 25, 2021, https://manplawyers.co/2017/06/15/alat-bukti-elektronik-dalamperkara-perdata/. 
KUHPerdata yang menjelaskan. "Persangkaan adalah kesimpulan yang oleh undang-undang atau oleh hakim ditarik dari suatu peristiwa yang diketahui umum ke arah suatu peristiwa yang tidak diketahui umum." 25 Pasal tersebut menyebutkan adanya Keyakinan Hakim, Pengetahuan umum, dan menjelaskan suatu peristiwa. Rekam CCTV ini bisa digunakan untuk mewakili pengetahuan umum tentang terjadinya peristiwa jika di tempat tersebut tidak ditemukan saksi mata. 26

Kembali kepada hakikat dari pembuktian dalam hukum acara perdata berarti memberikan kepastian secara yuridis, dengan sarana alat bukti, menetapkan secara pasti apa yang terjadi secara konkret dengan jalan mempertimbangkan atau memberikan alasan-alasan logis, sehingga sampai pada kesimpulan peristiwa-peristiwa tertentu dinyatakan benar atau dinyatakan tidak benar. Pada gilirannya para pihak dapat memperoleh gambaran yang jelas mengenai proses pengambilan keputusan dan alasan-alasan yang menjadi dasar pengambilan putusan tersebut. Putusan yang baik mengandung pertimbangan yang lengkap, akurat dan jelas. Namun dalam kasus gugatan terhadap hak cipta atas karya digital melalui file sharing saat ini masih terdapat kendala dalam hal menghadirkan alat bukti elektronik di persidangan dalam hal ini kendala tersebut meliputi kendala teknis, misalnya untuk memastikan orisinalitas bukti terkadang salah satu pihak yang berperkara meminta agar bukti yang dihadirkan harus disertai dengan keterangan ahli dalam hal ini ahli digital forensik yang dalam proses penggandaan harus dilakukan dan/atau diketahui oleh aparat penegak hukum. Ketiadaan aturan dan prosedur yang jelas mengenai alat bukti elektronik ini dapat membuat ketidakpastian hukum bagi penyidik maupun ahli digital forensik yang melakukan penyitaan atas perangkat yang mengandung bukti elektronik dan membuat pengadilan sulit untuk menilai integritas data/dokumen elektronik yang dihadirkan dalam pembuktian ${ }^{27}$. Selain itu. kendala non-teknis di antaranya data tidak terbaca, perangkat penyimpan data hilang dan lain-lain ${ }^{28}$.

\section{Penyelesaian Perdata Terkait Pembajakan Hak Cipta Atas Karya Digital Melalui File} Sharing di Indonesia

Aspek Kerugian terhadap Pembajakan Hak Cipta atas Karya Digital Melalui File Sharing

25 Ibid.

26 Ibid.

27 Dewi Asimah, “Menjawab Kendala Pembuktian dalam Alat Bukti Elektronik,” Jurnal Hukum Peratun Vol. 3, No. 2, 2020, hlm. 105.

28 Yustria Novi Satriana, "Eksistensi Digital Evidence dalam Hukum Acara Perdata Nurfauzah Maulidiyah," Jurnal Cakrawala Hukum Vol. 10, No. 1, 2019, hlm. 69-76. 
Maraknya kejahatan pembajakan karya digital melalui media file sharing tentunya tidak terlepas dari kultur masyarakat yang senang dengan sesuatu yang praktis dan mura, maka mereka pasti akan mencari barang-barang bajakan yang otomatis mempunyai harga jual yang lebih murah apabila dibandingkan dengan produk aslinya.

File sharing ilegal dilakukan terutama oleh "pembajak digital". Mereka menyalin dan mengunggah materi kepemilikan melalui Internet untuk dilihat dan diunduh oleh pengguna akhir tanpa persetujuan dari pemilik file. File yang dibagikan dapat berupa apa saja mulai dari dokumen, gambar, musik atau film hingga perangkat lunak. Materi yang dibagikan secara ilegal juga dikenal sebagai media atau konten bajakan. Jaringan P2P, aplikasi torrent, dan banyak situs web streaming film online adalah metode umum berbagi file ilegal ${ }^{29}$.

Cara pembajakan karya dilakukan dengan berbagai cara seiring berkembangnya teknologi, namun umumnya cara yang dilakukan adalah melakukan perekaman langsung dengan karya digital, penyalinan dari media penyimpanan lain, salinan orisinal ataupun bocoran (leaks), maupun perekaman dari media streaming.

Setelah mendapatkan salinan ilegal awal ini, pembajak meng-host salinan itu sendiri atau menjualnya kepada pengguna lain, yang disebut pengunggah, yang kemudian ditugaskan untuk mengunggahnya ke internet melalui beberapa bentuk file sharing, Paling umumnya adalah dengan menggunakan layanan seperti Google Drive, Mega, Mediafire, dan semacamnya. Konten ilegal yang di-hosting oleh cyberlocker atau jaringan P2P tidak mudah ditemukan. Materi bajakan mencapai pengguna akhir melalui perantara yang bertanggung jawab untuk mempromosikan konten tersebut: situs web bajakan.

Situs web konten bajakan sangat menarik bagi penggunanya, yang melalui penggunaan mesin pencari dan jejaring sosial dapat mengakses konten ilegal dengan cara yang sepenuhnya terbuka dan tidak terbatas. Sementara itu, penjahat dunia maya meraup keuntungan besar yang sangat besar. Cara paling umum untuk melakukan monetisasi adalah dengan memanfaatkan layanan iklan, baik itu iklan yang legit maupun iklan penipuan seperti iklan judi maupun iklan pornografi, penjualan data pengguna, sistem membership, dan metode Uploader Remuneration, yakni pembajak dunia maya menawarkan skema kompensasi kepada orang-orang yang mengunggah konten yang disalin untuk mendorong pengunggahan semacam itu.

Cara-cara yang dilakukan di atas pada dasarnya tidak terbatas pada film atau sinematografi saja. Perlakuan itu pula dapat terjadi pada karya digital lain seperti lagu, fotografi,

29 "llegal File Sharing," Techopedia, last modified 2016, diakses pada tanggal Juli 25, 2021, https://www.techopedia.com/definition/29931/illegal-file-sharing. 
perangkat lunak, maupun dokumen lainnya karena pada dasarnya file tersebut dapat dibagikan melalui file sharing. Di Indonesia sendiri, dari obyek-obyek tersebut di atas, yang memiliki angka tertinggi untuk dibajak adalah musik dan film ${ }^{30}$. Namun demikian, menurut hemat saya, semua jenis karya digital rawan dapat dilakukan pembajakan oleh orang yang tidak bertanggung jawab karena kerugian yang dialami oleh pencipta atau pemegang hak cipta tidaklah sedikit.

Meskipun Kementerian Komunikasi dan Informatika sudah menutup akses situs streaming film bajakan, akan tetapi sampai saat ini masih banyak ditemui situs ilegal yang menyebarkan konten film bajakan secara streaming sebagai pengganti dari situs yang sudah ditutup tersebut. Para pelaku pembuat situs film bajakan juga melakukan penggantian nama atau domain situs untuk mengelabui para penegak hukum dalam pelaksanaan tugasnya.

Keberadaan situs streaming film bajakan dan karya digital lainnya merupakan pelanggaran hukum terhadap hak cipta seseorang terhadap pembuatan film. Situs streaming film bajakan melanggar beberapa peraturan perundang-undangan, antara lain:

a. Pasal 113 ayat (3) dan (4) UUHC mengatakan bahwa setiap orang yang dengan tanpa hak dan/atau tanpa izin pencipta atau pemegang hak cipta melakukan pelanggaran hak ekonomi pencipta, apabila dilakukan dalam bentuk pembajakan, maka akan dipidana dengan pidana penjara paling lama 10 tahun dan/atau denda paling banyak 4 miliar rupiah.

b. Pasal 25 UU ITE menyatakan bahwa informasi elektronik dan/atau dokumen elektronik yang disusun menjadi karya intelektual, situs internet, dan karya intelektual yang ada di dalamnya dilindungi sebagai hak kekayaan intelektual berdasarkan ketentuan peraturan perundang-undangan.

Selain itu aturan mengenai hak cipta juga berlaku di berbagai negara melalui Berne Convention for the Protection of Literary and Artistic Works (Berne Convention). Berne Convention berlaku bagi negara-negara penandatanganan konvensi sebagaimana dinyatakan dalam Pasal 1 bahwa "The countries to which this Convention applies constitute a Union for the protection of the rights of authors in their literary and artistic works." Kemudian pada Pasal 2 angka 1 diatur pula mengenai ciptaan apa saja yang dilindungi, sebagaimana berikut ini.

"The expression "literary and artistic works" shall include every production in the literary, scientific and artistic domain, whatever may be the mode or form of its expression, such as books, pamphlets and other writings; lectures, addresses, sermons and other works of the

30 "Dirjen HAKI: Musik \& Film Obyek Terbanyak Dibajak di Internet," Detikcom, last modified 2012, diakses pada tanggal Juli 25, 2021, https://news.detik.com/berita/d-1901108/dirjen-haki-musik--film-obyekterbanyak-dibajak-di-internet-. 
same nature; dramatic or dramatico-musical works; choreographic works and entertainments in dumb show; musical compositions with or without words; cinematographic works to which are assimilated works expressed by a process analogous to cinematography; works of drawing, painting, architecture, sculpture, engraving and lithography; photographic works to which are assimilated works expressed by a process analogous to photography; works of applied art; illustrations, maps, plans, sketches and three-dimensional works relative to geography, topography, architecture or science."

Dan Pasal 2 angka 6 menegaskan bahwa Ciptaan tersebut harus mendapatkan perlindungan di negara-negara penandatanganan konvensi. "The works mentioned in this Article shall enjoy protection in all countries of the Union. This protection shall operate for the benefit of the author and his successors in title." Sedangkan Pasal 9 angka 1 dari Berne Convention menyatakan: "Authors of literary and artistic works protected by this Convention shall have the exclusive right of authorizing the reproduction of these works, in any manner or form."

Pada level internasional HKI diatur dalam perjanjian Trade Related Aspects on Intellectual Property Rights (selanjutnya disebut TRIPS). Perjanjian TRIPS ini merupakan standar perlindungan HKI pada level internasional yang telah disepakati oleh negara-negara sebagai bagian dari kesepakatan perdagangan multilateral dalam kerangka pembentukan World Trade Organization (selanjutnya disebut WTO). ${ }^{31}$ Aturan yang bersumber dari kesepakatan negara-negara di dunia inilah yang kemudian diadopsi oleh negara-negara penandatanganan konvensi, salah satunya adalah Indonesia. Dalam hukum hak cipta Indonesia, yaitu Undang-Undang No. 28 Tahun 2014 tentang Hak Cipta, diatur mengenai bagaimana hak eksklusif yang dimiliki oleh Pencipta wajib mendapatkan perlindungan.

Aspek kerugian materiil dan non materiil pencipta karya digital dalam hal pembajakan hak cipta karya digital untuk memperoleh keuntungan ekonomi, ini adalah tidak terpenuhinya hak eksklusif Pencipta atau mendapatkan manfaat ekonomi dari hasil ciptaannya dalam bentuk royalti. Royalti yang dimaksud adalah imbalan atas pemanfaatan hak ekonomi suatu Ciptaan atau produk hak terkait yang diterima oleh pencipta atau pemilik hak terkait.

\section{Kewenangan Mengadili Perkara Gugatan terhadap Pembajakan Hak Cipta atas Karya Digital Melalui File Sharing}

Dalam hal terjadi sengketa perdata antara penggugat dan tergugat yang memilih menyelesaikan sengketa melalui lembaga peradilan, tentunya berbicara tentang lembaga

31 Safril Sofwan Sanib, "Ketentuan-ketentuan TRIPS-Plus dalam Kerangka Perjanjian Perdagangan Bebas TRIPS-Plus Provisions Under a Frame of Bilateral Free Trade Agreement," Halu Oleo Law Review Vol. 3, No. 1, 2019, hlm. 51. 
peradilan juga harus menyinggung tentang pengadilan mana yang berwenang mengadili, mengenai kekuasaan mengadili, maka hal ini berkaitan dengan kompetensi dari badan pengadilan. Suatu gugatan harus diajukan kepada badan peradilan yang benar-benar berwenang untuk mengadili persoalan ini.

Para pihak harus memperhatikan asas yang berlaku dalam gugat-menggugat melalui pengadilan. Satu asas yang cukup penting adalah siapa yang mendalilkan, wajib membuktikan kebenaran dalilnya ${ }^{32}$. Asas ini dijabarkan dalam Pasal 1865 KUHPerdata yang mengemukakan bahwa: "Setiap orang yang mendalilkan bahwa ia mempunyai sesuatu hak atau guna meneguhkan haknya sendiri maupun membantah suatu hak orang lain, menunjuk suatu peristiwa, diwajibkan membuktikan adanya hak atau peristiwa tersebut." Untuk itu, jika penyelesaian sengketa bisnis dipilih lewat lembaga peradilan, ada beberapa hal yang perlu dipertimbangkan, yakni pihak penggugat wajib membuktikan kebenaran dalilnya. Di samping itu, penggugat harus tahu persis di mana tempat tinggal tergugat, gugatan harus diajukan di tempat tinggal tergugat, Asas ini dikenal dengan istilah Actor Secuitor Forum Rei.

Dalam penegakan hukum perdata terkait kerugian dalam tindakan pembajakan hak cipta atas karya digital melalui file sharing, pengadilan yang berwenang mengadili perkara gugatan terhadap pembajakan hak cipta atas karya digital melalui file sharing dilakukan melalui Pengadilan Niaga, yang mana dirancang untuk diperluas kompetensinya. Saat ini perluasan kompetensi itu mencakup kewenangan untuk memeriksa masalah-masalah yang terkait dengan Hak atas Kekayaan Intelektual (HaKI), yang meliputi kewenangan memeriksa sengketa merek, paten, desain industri, dan desain tata letak sirkuit terpadu.

Dalam UUHC, wewenang Pengadilan Niaga dalam penyelesaian sengketa hak cipta telah dengan jelas tercantum dalam Bab XIV dan Bab XV dari Pasal 95 sampai Pasal 109. Pada Pasal 95, penyelesaian sengketa Hak Cipta dapat dilakukan melalui Alternatif Penyelesaian Sengketa (ADR), arbitrase, atau Pengadilan Niaga. Selain Pengadilan Niaga, pengadilan lain tidak berwenang menangani penyelesaian sengketa Hak Cipta. Hal ini diperkuat dengan berdasarkan Penjelasan Pasal 27 ayat (1) Undang-Undang Nomor 48 Tahun 2009 tentang Kekuasaan Kehakiman, pengadilan niaga merupakan salah satu bentuk pengadilan khusus yang berada di lingkungan peradilan umum.

Dari ketentuan Pasal 95 UUHC, selain dapat diselesaikan melalui Pengadilan Niaga, juga dapat diselesaikan melalui Arbitrase atau ADR. Penyelesaian sengketa Hak Cipta melalui ADR

32 Apri Rotin Djusfi, "Penyelesaian Sengketa Hibah Menurut Kitab Undang-Undang Hukum Perdata," Jurnal Ius Civilie Vol. 2, 2018, hlm. 117. 
dapat dilakukan melalui negosiasi, mediasi, konsolidasi, atau melalui cara lain yang dipilih oleh para pihak sesuai dengan undang-undang yang berlaku yang mengatur mengenai ADR $^{33}$. Namun, sepanjang para pihak yang bersengketa diketahui keberadaannya dan/atau berada di wilayah Negara Kesatuan Republik Indonesia harus menempuh terlebih dahulu penyelesaian sengketa melalui mediasi sebelum melakukan tuntutan pidana. Artinya penyelesaian sengketa melalui jalur pidana adalah sebagai upaya terakhir dalam penyelesaian sengketa Hak Cipta.

Dalam Pengadilan Niaga, dikenal dengan penetapan sementara, yakni Pencipta, pemegang hak cipta atau hak terkait dapat mengajukan permohonan penetapan sementara kepada Pengadilan Niaga. Menurut Pasal 99 ayat (4) UUHC, permohonan tersebut dapat dilakukan untuk meminta penyitaan atas ciptaan yang dilakukan pengumuman atau penggandaan, atau alat penggandaan yang digunakan si pelanggar, juga untuk menghentikan kegiatan pengumuman, pendistribusian, komunikasi dan/atau penggandaan ciptaan. Terdapat pula Upaya Perdata, yakni pencipta, pemegang hak cipta atau hak terkait, ataupun ahli warisnya berhak memperoleh ganti rugi atas pelanggaran hak cipta atau produk hak terkait.

Sebelum mengajukan gugatan, ada beberapa dokumen yang harus disiapkan, yakni surat kuasa (apabila menggunakan kuasa hukum), identitas pencipta atau pemegang hak cipta atau hak terkait, atau akta pendirian apabila penggugat merupakan badan hukum, surat pencatatan hak cipta (apabila dicatatkan) atau bukti kepemilikan hak cipta lainnya, contoh wujud ciptaan, petunjuk awal terjadinya pelanggaran hak cipta atau hak terkait, dan hitungan ganti rugi.

Untuk mengajukan gugatan ganti rugi di Pengadilan Niaga, pertama harus mengajukan gugatan atas pelanggaran hak cipta kepada ketua Pengadilan Niaga. Kemudian pencatatan gugatan dalam register perkara pengadilan pada tanggal pendaftaran gugatan oleh panitera. Panitera akan memberikan tanda terima yang telah ditandatangani dan menyampaikan permohonan gugatan kepada ketua Pengadilan Niaga maksimal 2 hari sejak tanggal pendaftaran gugatan. Setelah itu, penetapan hari sidang akan dikeluarkan maksimal 3 hari sejak gugatan didaftarkan. Kemudian, juru sita akan memberitahu dan memanggil para pihak maksimal 7 hari sejak pendaftaran gugatan. Pembacaan putusan atas gugatan dalam sidang terbuka untuk umum, maksimal diucapkan 90 haru sejak gugatan didaftarkan. Apabila tidak dapat dipenuhi, maka dapat diperpanjang selama 30 hari.

33 Oemar Wongsodiwirjo, "Perlindungan Hukum Bagi Pencipta," Yuridika 4, No. II, 1987; Lihat juga dalam Eben Paulus Muaja, "Kewenangan Pengadilan Niaga dalam Penyelesaian Sengketa HAKI di Bidang Hak Cipta Menurut Undang-Undang Nomor 28 Tahun 2014," Lex Crimen VII, No. 6, 2018, hlm. 92. 
Penyelesaian sengketa pelanggaran hak cipta, di samping dapat di gugat di Pengadilan Niaga, UUHC juga mengatur tentang tindak pidana hak cipta, yang diatur dalam bab XVI dan Bab XVII dari Pasal 110 dan Pasal 120. Penyelesaian tindak pidana hak cipta tersebut diajukan ke Pengadilan Negeri dan hukum acara yang berlaku sebagaimana ketentuan menurut UndangUndang Nomor 8 Tahun 1981 tentang KUHAP.

\section{Penyelesaian Perdata Terkait Pembajakan Hak Cipta atas Karya Digital Melalui File}

\section{Sharing di Indonesia}

Terdapat beberapa bentuk Penyelesaian sengketa Hak Cipta yang diatur dalam UUHC, penyelesaian tersebut dapat dilakukan melalui ADR, arbitrase, atau pengadilan. ADR mempunyai beberapa mekanisme yang bisa dipilih oleh para pihak untuk menyelesaikan sengketa, di antaranya yang paling populer adalah Negosiasi, Pendapat Mengikat, Mediasi dan Arbitrase. Adapun proses penyelesaian melalui jalur peradilan adalah melayangkan gugatan pada pengadilan yang berwenang berdasarkan undang-undang yakni Pengadilan Niaga, selain dari pada itu pengadilan tersebut harus dinyatakan tidak berwenang menangani penyelesaian sengketa Hak Cipta.

Tata cara gugatan pelanggaran hak cipta yang diatur pada aturan sebagai berikut.

Pasal 100 UU HC

1. Gugatan atas pelanggaran Hak Cipta diajukan kepada ketua Pengadilan Niaga.

2. Gugatan sebagaimana dimaksud pada ayat (1) dicatat oleh panitera Pengadilan Niaga dalam register perkara pengadilan pada tanggal gugatan tersebut didaftarkan.

3. Panitera Pengadilan Niaga memberikan tanda terima yang telah ditandatangani pada tanggal yang sama dengan tanggal pendaftaran.

4. Panitera Pengadilan Niaga menyampaikan permohonan gugatan kepada ketua Pengadilan Niaga dalam waktu paling lama 2 (dua) Hari terhitung sejak tanggal gugatan didaftarkan.

5. Dalam waktu paling lama 3 (tiga) Hari terhitung sejak gugatan didaftarkan, Pengadilan Niaga menetapkan Hari sidang.

6. Pemberitahuan dan pemanggilan para pihak dilakukan oleh juru sita dalam waktu paling lama 7 (tujuh) Hari terhitung sejak gugatan didaftarkan.

Pasal 101 UU HC

1. Putusan atas gugatan harus diucapkan paling lama 90 (sembilan puluh) Hari sejak gugatan didaftarkan.

2. Dalam hal jangka waktu sebagaimana dimaksud pada ayat (1) tidak dapat dipenuhi, atas persetujuan Ketua Mahkamah Agung jangka waktu tersebut dapat diperpanjang selama 30 (tiga puluh) Hari.

3. Putusan sebagaimana dimaksud pada ayat (1) harus diucapkan dalam sidang terbuka untuk umum. 
4. Putusan Pengadilan Niaga sebagaimana dimaksud pada ayat (3) harus disampaikan oleh juru sita kepada para pihak paling lama 14 (empat belas) Hari terhitung sejak putusan diucapkan.

Selain aspek gugatan perdata di Pengadilan Niaga, UUHC juga memberikan ruang terhadap kejahatan pembajakan untuk dilaporkan ke kepolisian untuk diproses secara pidana. Bentuk delik dalam tindak pidana hak cipta adalah delik aduan berdasarkan Pasal 120 UUHC yang konsekuensi hukumnya adalah apabila pelapor mencabut aduannya maka tindak pidana tersebut dinyatakan selesai dan tidak diproses pada tahap selanjutnya. Keterkaitan antara proses pidana dan proses pembuktian dalam gugatan pembajakan hak cipta karya digital adalah karena rumitnya menemukan alat bukti di persidangan, penggugat dapat menunggu putusan pidana yang berkekuatan hukum tetap mengenai apakah tergugat terbukti secara sah dan meyakinkan melakukan pembajakan dan putusan tersebut dapat diajukan sebagai salah satu bukti penunjang untuk memperkuat dalil dalam gugatan.

\section{KESIMPULAN}

Bentuk pembuktian pembajakan hak cipta atas karya digital melalui file sharing di Indonesia adalah pada umumnya sama dengan pembuktian dalam hukum acara perdata asas actori incumbit probatio yang berarti barang siapa mempunyai sesuatu hak atau mengemukakan suatu peristiwa harus membuktikan adanya hak atau peristiwa itu. Mengenai alat bukti juga memiliki kesamaan namun karena domain pembajakan atas karya digital melalui file sharing adalah dengan media komputer atau sejenisnya sehingga dimungkinkan alat bukti elektronik, yang memiliki kendala teknis berupa pembuktian orisinalitas dari alat bukti yang dihadirkan. Sedangkan kendala non teknis berupa rentannya kerusakan serta hilangnya barang bukti elektronik yang disimpan. Selain itu, bentuk penyelesaian perdata terkait pembajakan hak cipta atas karya digital melalui file sharing di Indonesia adalah terdapat beberapa bentuk Penyelesaian sengketa Hak Cipta yang diatur dalam Undang-Undang Nomor 28 Tahun 2014 tentang Hak Cipta. Penyelesaian tersebut dapat dilakukan melalui alternatif penyelesaian sengketa, arbitrase, atau pengadilan. Untuk penyelesaian sengketa dikenal istilah Negosiasi, Pendapat Mengikat, Mediasi, dan Arbitrase. Sedangkan melalui peradilan dalam UndangUndang Nomor 28 Tahun 2014 tentang Hak Cipta, pengadilan yang berwenang adalah pengadilan niaga, namun tidak meratanya domisili pengadilan niaga di tiap daerah menjadikan tidak semua subjek yang mengalami kerugian atas pembajakan digital mendapatkan haknya karena terkendala jarak. 


\section{Daftar Pustaka}

\section{Buku}

Effendie, Bahtiar, Tasmin Masdari, dan A. Chodari. Surat Gugat Dan Hukum Pembuktian Dalam Perkara Perdata. Bandung: Citra Aditya Bakti, 1999.

Fakhriah, Efa Laela. Bukti Elektronik dalam Sistem Pembuktian Perdata. 2 ed. Bandung: Alumni, 2013.

Hadikusuma, Hilman. Metode Pembuatan Kertas Kerja atau Skripsi Ilmu Hukum. Bandung: Mandar Maju, 1995.

Harahap, M. Yahya. Kumpulan Makalah Hukum Acara Perdata, 1991.

Isnaini, Yusran. Hak Cipta dan Tantangannya di Era Cyber Space. Bogor: Ghalia Indonesia, 2009.

Muhammad, Abdulkadir. Hukum Acara Perdata Indonesia. Bandung: Alumni, 1978.

Projodikoro, Wirjono. Hukum Acara Perdata di Indonesia. Bandung: Sumur Bandung, 1992.

Samudera, Teguh. Hukum Pembuktian Dalam Acara Perdata. 1 ed. Bandung: Alumni, 1992.

Subekti, R. Hukum Pembuktian. Jakarta: Pradnya Paramita, 1991.

Sutantio, Retnowulan, dan Iskandar Oeripkartawinata. Hukum Acara Perdata dalam Teori dan Praktek. Bandung: Mandar Maju, 1995.

\section{Jurnal}

Asimah, Dewi. “Menjawab Kendala Pembuktian dalam Alat Bukti Elektronik." Jurnal Hukum Peratun Vol. 3, No. 2, 2020.

Djusfi, Apri Rotin. "Penyelesaian Sengketa Hibah Menurut Kitab Undang-Undang Hukum Perdata." Jurnal Ius Civilie Vol. 2, 2018.

Muaja, Eben Paulus. "Kewenangan Pengadilan Niaga dalam Penyelesaian Sengketa HAKI di Bidang Hak Cipta Menurut Undang-Undang Nomor 28 Tahun 2014." Lex Crimen Vol. VII, No. 6, 2018.

Oberholzer-Gee, Felix, dan Koleman Strumpf. “File Sharing and Copyright.” Innovation Policy and the Economy Vol. 10, 2010. http://www.journals.uchicago.edu/doi/10.1086/605852.

Safril Sofwan Sanib. “Ketentuan-ketentuan TRIPS-Plus dalam Kerangka Perjanjian Perdagangan Bebas TRIPS-Plus Provisions Under a Frame of Bilateral Free Trade Agreement." Halu Oleo Law Review Vol. 3, No. 1, 2019.

Satriana, Yustria Novi. "Eksistensi Digital Evidence dalam Hukum Acara Perdata Nurfauzah Maulidiyah." Jurnal Cakrawala Hukum Vol. 10, No. 1. 2019. 
Syahputra, Dimas Febrian, Rivan Kurniawan, dan Yusuf Bintang Syaifinuha. "Perlindungan Hukum Transaksi E-Commerce." Privat Law Vol. 7, 2015.

Wahyudi, Johan. "Dokumen Elektronik Sebagai Alat Bukti Pada Pembuktian di Pengadilan." Perspektif, Vol. 17, No. 2, 2012.

Wongsodiwirjo, Oemar. “Perlindungan Hukum Bagi Pencipta.” Yuridika Vol. 4, No. II, 1987.

\section{Situs web}

"2 Cara Download Film IndoXXI di Android atau Laptop Terbaru 2019." Kuotamedia.net. https://kuotamedia.net/hiburan/film/cara-download-film-indoxxi/. diakses pada tanggal 3 Maret 2020.

“Alat Bukti Elektronik dalam Perkara Perdata." Michael Agusting \& Partners Lawyers. https://manplawyers.co/2017/06/15/alat-bukti-elektronik-dalam-perkara-perdata/, diakses pada tanggal 25 Juli 2021

"Dirjen HAKI: Musik \& Film Obyek Terbanyak Dibajak di Internet." Detikcom. https://news.detik.com/berita/d-1901108/dirjen-haki-musik--film-obyek-terbanyakdibajak-di-internet-, diakses pada tanggal 25 Juli 2021

"llegal File Sharing." Techopedia. https://www.techopedia.com/definition/29931/illegal-filesharing, diakses pada tanggal 25 Juli 2021.

Anisa, Dina Fitri. “Film Keluarga Cemara Dibajak, Visinema Pictures Giring Pelaku ke Pengadilan." Berita Satu. https://www.beritasatu.com/hiburan/725189/film-keluarga-cemaradibajak-visinema-pictures-giring-pelaku-ke-pengadilan, diakses pada 10 Agustus 2021.

Aulia, Rafika. “Menteri Amir: Pelanggaran Hak Cipta Merugikan.” Tempo.co. https://nasional.tempo.co/read/399773/menteri-amir-pelanggaran-hak-ciptamerugikan, diakses pada tanggal 3 Maret 2020.

Budiansyah, Arif. "Tutup Januari 2020, Ini Cara IndoXXI Dapat Film Baru \& Cuan.” CNBC Indonesia. $\quad$ https://www.cnbcindonesia.com/tech/20191230073207-37126373/tutup-januari-2020-ini-cara-indoxxi-dapat-film-baru-cuan, diakses pada tanggal 4 Maret 2020.

Fakhriah, Efa Laela. Sistem Pembuktian Terbuka Dalam Penyelesaian Sengketa Perdata Secara Litigasi. Bandung: Universitas Padjajaran, 2012. http://pustaka.unpad.ac.id/wpcontent/uploads/2012/05/pustaka_unpad_sistem_pembuktian.pdf.

Iskandar. "Headline: Situs IndoXXI Tutup, Kemkominfo Blokir Massal Web Streaming Ilegal?" Liputan6.com. https://www.liputan6.com/tekno/read/4142549/headline-situs- 
indoxxi-tutup-kemkominfo-blokir-massal-web-streaming-ilegal, diakses pada tanggal 2 Maret 2020.

Rahman, Adi Fida. “Tepati Janji, IndoXXI Resmi Tutup Layanan." Detikcom. https://inet.detik.com/cyberlife/d-4842340/tepati-janji-indoxxi-resmi-tutup-layanan, diakses pada tanggal 3 Maret 2020. 